\title{
SIMULATION, VALIDATION AND APPLICATION OF CERES- MAIZE MODEL FOR YIELD MAXIMIZATION OF MAIZE IN NORTH WESTERN HIMALAYAS
}

\author{
RAMAWAT, N. ${ }^{1}-$ SHARMA, H.L. ${ }^{1}-$ KUMAR, R. ${ }^{2} *$ \\ ${ }^{I}$ Chaudhary Sarwan Kumar Himachal Pradesh Agricultural University, \\ Palampur, 176062 (HP) India \\ (phone: + 911894 233307; fax: + 911894 230511) \\ ${ }^{2}$ Institute of Himalayan Bioresource Technology (CSIR), \\ Palampur, 176061 (HP) India \\ (phone: +91 1894 233341; fax: +91 1894230433 ) \\ *Corresponding author \\ e-mail: rakeshkumar@ihbt.res.in
}

(Received 23 $3^{\text {rd }}$ April 2008; accepted $10^{\text {th }}$ February 2012)

\begin{abstract}
Maize (Zea mays L.) is one of the most important cereal crops of the world. Investigations were carried out for determination of genotypic coefficients of important varieties of maize by using CERES-Maize model in the Decision Support System for Agrotechnology Transfer (DSSAT v 3.5). The CERES-Maize model was evaluated with experimental data collected during two field experiments conducted in Palampur, India. Field experiments comprising of four dates of sowing (June 1, June 10, June 20 and June 30) and four varieties (KH 9451, KH 5991, early composite and local) of maize were conducted during Summer 2003 and 2004 in split plot design. Observations on development stages, dry matter accumulation at 15 days interval, yield attributes, yield (grains, stover and biological), nitrogen content and uptake were recorded. Genotypic coefficients of important varieties of maize were worked out. CERES-Maize model successfully simulated phenological stages, yield attributes (except single grain weight), yield and also $\mathrm{N}$ uptake with coefficient of variation (CV) nearly equal to $10 \%$. CERES-Maize model was validated with fair degree of accuracy. Simulation guided management practices were worked out under potential production and resource limiting situations. Best time of sowing of both hybrids (KH 9451, KH 5991) was worked out to be last week of April. While for early composite (EC), first week of May proved advantageous and for local variety second fortnight of April was the best time of sowing. The best schedule of $\mathrm{N}$ application was $60 \mathrm{~kg} \mathrm{ha}^{-1}$ at sowing time and $30 \mathrm{~kg} \mathrm{ha}^{-1}$ at knee high stage for all varieties except for local where it was $60 \mathrm{~kg} \mathrm{ha}^{-1}$ at sowing and $30 \mathrm{~kg} \mathrm{ha}^{-1}$ each at knee high and silking stages.
\end{abstract}

Keywords: Crop simulation, CERES-Maize, Yield, Decision Support, Validation

\section{Introduction}

Increased food grain production depends upon judicious use of resources. The soil, climate, genotype and management factors determine the response of crops to irrigation, fertilizer and other inputs. Working out appropriate crop management strategies under uncertainties of weather and other resources have major economic and environmental implications. Computer simulation models of the soil-crop-atmosphere system can make a valuable contribution to both advancing our understanding of the processes determining crop responses and predicting crop performance in different regions and decision making system. It facilitates the task of optimizing crop and nutrient management and also investigates environmental and sustainability issues of agroecosystem. A scientific model can be defined as an abstraction of some real system that can be used for purposes of prediction and control. Crop simulation models are 
mathematical representations of plant growth processes as influenced by interactions among genotype, environment, and crop management. They have become an indispensable tool for supporting scientific research, crop management, and policy analysis (Fischer et al., 2000; Hammer et al., 2002; Hansen 2002).

Crop simulation models have been used for many different applications in various countries around the world. The Decision Support System for Agrotechnology Transfer (DSSAT v 3.5) is a comprehensive decision support system (Hoogenboom et al., 2004; Tsuji et al., 1994) that includes the CERES-Maize model (Jones et al., 2003; Ritchie et al., 1998). Crop growth and development are simulated by the CERES-Maize model with a daily time step from planting to maturity and are based on physiological processes that describe the response of maize to soil and aerial environmental conditions. Potential growth is dependent on photosynthetically active radiation and its interception, whereas actual biomass production on any day is constrained by suboptimal temperatures, soil water deficits, and nitrogen deficiencies.

Crop simulation models can predict crop yields well before harvest by using expected or historical weather data. Crop performance can also be predicted for climates where the crop has not ever been grown before or not grown under normal conditions. The models can be used to address various management options like scheduling of irrigation (Boggess and Ritchie 1988; Bosch and Ross 1990), scheduling of $\mathrm{N}$ fertilization, time of sowing (Anapalli et al., 2005), risk analysis in rainfed cropping, selection of suitable varieties under varying agro-climatic situations, etc. Besides, they can also be used for rational planning of field experiments and as a teaching aid. A major advantage of models is their ability to simulate the temporal components of crop production. This capability allows models to evaluate different crop management scenarios with less cost and in short time (Reddy and Umamaheshwari 2004).

To simulate, yield, crop growth parameters, soil water and nutrient balances, the model requires a minimum set of data on certain parameters viz. (i) weather parameters (solar radiation, maximum and minimum temperature and rainfall on daily basis), (ii) soil characteristics (soil texture, bulk density, volumetric water content at field capacity and permanent wilting point), (iii) genotypic coefficients which define the varietal characteristics of each variety to be used in the model and (iv) crop management consisting of time of different field operations. Therefore, generation of minimum data set for validation of the model is a prerequisite.

In Himachal Pradesh, models capable of forecasting maize as a decision support system are yet to be tested. Also, input data sets on 'genotypic coefficients' for the varieties cultivated in Himachal Pradesh are lacking. The present study proposes to generate and compile the minimum data set required to test the validity of CERESMaize model.

\section{Materials and methods}

\section{Site description}

Field experiments on maize crop were conducted at the experimental farm of Department of Agronomy, Chaudhary Sarwan Kumar Himachal Pradesh Agricultural University, Palampur (32 $6^{\prime} \mathrm{N}$ latitude, $76^{\circ} 3^{\prime} \mathrm{E}$ longitude, and $1290.8 \mathrm{~m}$ elevation above mean sea level). Before conducting experiments, soil samples from 0-15, 15-30, 30-45 and 45-60 cm depth were collected. Results of various physicochemical properties of soil have been summarized in Table 1 . 
The soil at the experimental field was silty clay loam in texture, acidic in reaction. The $0-60 \mathrm{~cm}$ soil layer had on an average bulk density of $1.35 \mathrm{~g} \mathrm{~cm}^{-3}$. Moisture content at $0.3 \mathrm{~atm}$ and at $15 \mathrm{~atm}$ suction was about 0.27 and $0.19 \mathrm{~cm} \mathrm{~cm}^{-3}$. Soil was rich in organic matter in the upper layer that decreased with increase in soil depth. The soil was rated as high in total $\mathrm{N}$, and medium in available $\mathrm{P}_{2} \mathrm{O}_{5}$ and $\mathrm{K}_{2} \mathrm{O}$ in upper $0-15 \mathrm{~cm}$ layer in both seasons. These values decreased with soil depth.

Agroclimatically the experimental area falls in sub-temperate humid zone. On an average, annual rainfall of the place is $2500 \mathrm{~mm}$, of which about $80 \%$ is received during June to September. Weather data recorded at the Meteorological Observatory of Department of Agronomy, during the crop season 2003 and 2004 has been illustrated in Figs. 1 and 2, respectively.

Table 1. Physicochemical properties of experimental soil

\begin{tabular}{|c|c|c|c|c|c|}
\hline \multirow[t]{2}{*}{ Properties } & \multicolumn{4}{|c|}{ Layer $(\mathrm{cm})$} & \multirow[t]{2}{*}{ Method employed } \\
\hline & $0-15$ & $15-30$ & $30-45$ & $45-60$ & \\
\hline \multicolumn{5}{|l|}{ A. Physical properties } & \\
\hline Sand $(\%)$ & 19.1 & 17.7 & 18.5 & 29.1 & $\begin{array}{l}\text { International Pipette } \\
\text { method (Piper, 1966) }\end{array}$ \\
\hline Silt (\%) & 43.2 & 37.7 & 35.0 & 23.2 & \\
\hline Clay $(\%)$ & 37.7 & 44.6 & 46.5 & 47.7 & \\
\hline Bulk density $\left(\mathrm{g} \mathrm{cm}^{-3}\right)$ & 1.35 & 1.43 & 1.33 & 1.33 & Core sampler technique \\
\hline $\begin{array}{l}\text { Moisture content at } 0.3 \\
\text { atm suction }\left(\mathrm{cm}^{3} \mathrm{~cm}^{-3}\right)\end{array}$ & 0.267 & 0.269 & 0.270 & 0.270 & $\begin{array}{l}\text { Pressure plate apparatus } \\
\text { (Richards, 1965) }\end{array}$ \\
\hline $\begin{array}{l}\text { Moisture content at } 15 \\
\text { atm suction }\left(\mathrm{cm}^{3} \mathrm{~cm}^{-3}\right)\end{array}$ & 0.166 & 0.195 & 0.195 & 0.190 & $\begin{array}{l}\text { Pressure plate apparatus } \\
\text { (Richards, 1965) }\end{array}$ \\
\hline \multicolumn{6}{|l|}{ B. Chemical properties } \\
\hline $\mathrm{pH}$ & 5.6 & 5.5 & 5.6 & 5.5 & $\begin{array}{l}\text { 1:2.5 soil water suspension } \\
\text { glass electrode } \mathrm{pH} \text { meter } \\
\text { (Jackson, 1967) }\end{array}$ \\
\hline Organic Carbon (\%) & 1.06 & 0.87 & 0.73 & 0.71 & $\begin{array}{l}\text { Walkley and Black's Rapid } \\
\text { titration method (Piper, } \\
\text { 1966) }\end{array}$ \\
\hline Total nitrogen $\left(\mathrm{kg} \mathrm{ha}^{-1}\right)$ & 3592 & 3143 & 2470 & 449 & $\begin{array}{l}\text { Modified Kjeldahl's } \\
\text { method (Jackson, 1967) }\end{array}$ \\
\hline $\mathrm{NO}_{3}^{-} \mathrm{N}\left(\mathrm{kg} \mathrm{ha}^{-1}\right)$ & 13.47 & 12.35 & 6.74 & 2.25 & $\begin{array}{l}\text { Steam Distillation method } \\
\text { (Jackson, 1967) }\end{array}$ \\
\hline $\mathrm{NH}_{4}^{+} \mathrm{N}\left(\mathrm{kg} \mathrm{ha}^{-1}\right)$ & 168.38 & 121.23 & 78.58 & 2.25 & \\
\hline $\begin{array}{l}\text { Available phosphorous } \\
\left(\mathrm{kg} \mathrm{P}_{2} \mathrm{O}_{5} \mathrm{ha}^{-1}\right)\end{array}$ & 22.1 & 22.0 & 19.3 & 20.0 & $\begin{array}{l}\text { Olsen's Method (Olsen et } \\
\text { al., 1954) }\end{array}$ \\
\hline $\begin{array}{l}\text { Available potassium } \\
\left(\mathrm{kg} \mathrm{K}_{2} \mathrm{O} \mathrm{ha}^{-1}\right)\end{array}$ & 269 & 292 & 269 & 269 & $\begin{array}{l}\text { Neutral normal ammonium } \\
\text { acetate method (Black, } \\
\text { 1965) }\end{array}$ \\
\hline
\end{tabular}

During Summer 2003, weekly minimum temperature ranged between $22.6{ }^{\circ} \mathrm{C}$ in $23^{\text {rd }}$ standard week $\left(4^{\text {th }}-10^{\text {th }}\right.$ June $)$ to $15.1^{\circ} \mathrm{C}$ in $43^{\text {rd }}$ standard week $\left(22^{\text {nd }}-28^{\text {th }}\right.$ October $)$ in 2003 and $21.0^{\circ} \mathrm{C}$ in $27^{\text {th }}$ standard week $\left(2^{\text {nd }}-8^{\text {th }} \mathrm{July}\right)$ to $15.6^{\circ} \mathrm{C}$ in $40^{\text {th }}$ standard week $\left(1-7^{\text {th }}\right.$ October) during second year of experimentation. Mean weekly maximum temperature during the year 2003 ranged between $35.6{ }^{\circ} \mathrm{C}$ in $23^{\text {rd }}$ standard week $\left(4^{\text {th }}\right.$ $10^{\text {th }}$ June $)$ to $25.3{ }^{\circ} \mathrm{C}$ in $43^{\text {rd }}$ standard week $\left(22^{\text {nd }}-28^{\text {th }}\right.$ October $)$ and during summer 2004 , between $31.1^{\circ} \mathrm{C}$ in $22^{\text {nd }}$ standard week (28 May- $3^{\text {rd }}$ June) and $23.5^{\circ} \mathrm{C}$ in $40^{\text {th }}$ standard week $\left(1-7^{\text {th }}\right.$ October $)$. 


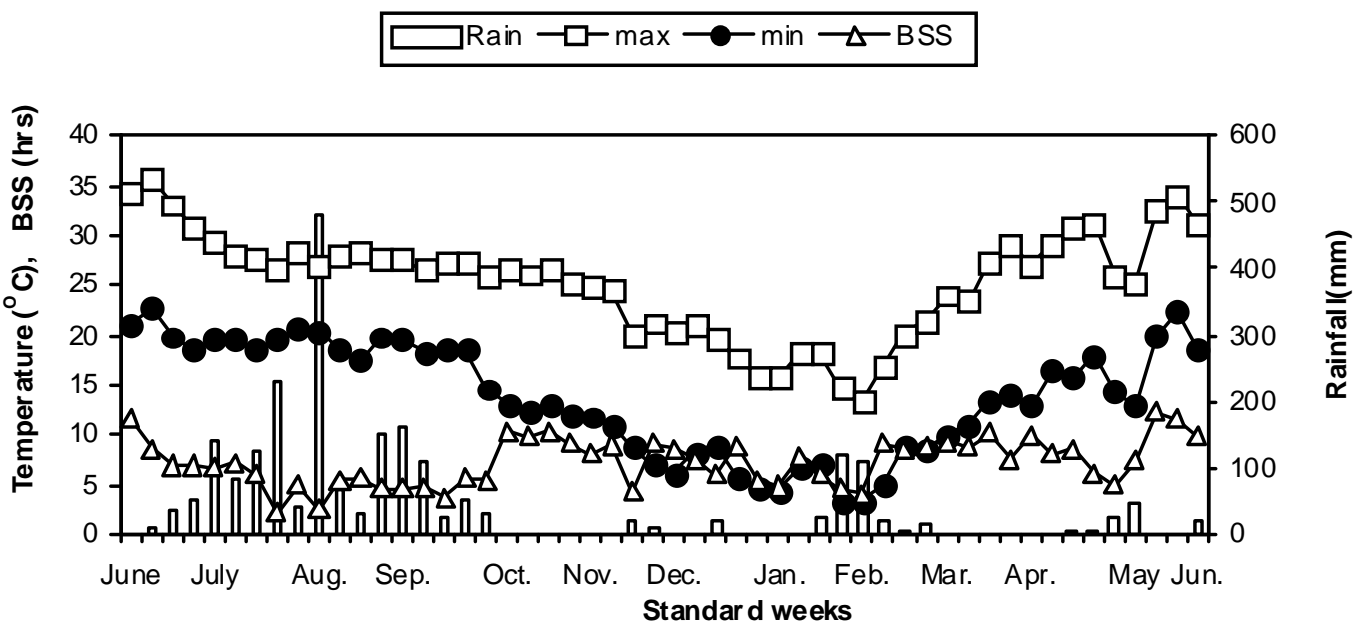

Figure 1. Week-wise meteorological observations from $28^{\text {th }}$ May 2003 to $28^{\text {th }}$ May 2004 of Palampur

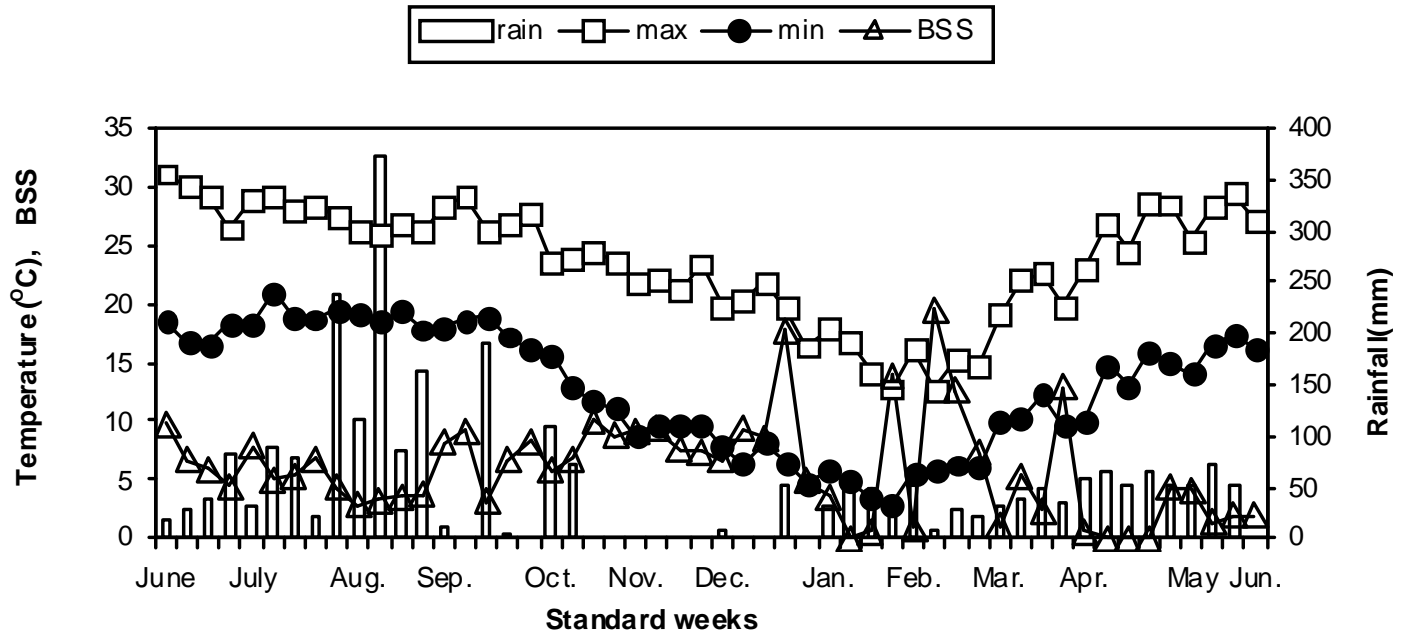

Figure 2. Week-wise meteorological observations from $28^{\text {th }}$ May 2004 to $28^{\text {th }}$ May 2005 of Palampur

\section{Field experiments}

Two field experiments on maize crop were conducted in Summer 2003 and 2004 in split plot design with a combination of four dates of sowing (June 1- D1; June 10- D2; June 20- D3; June 30- D4) and four varieties [KH 9451 (Hybrid) - V1; KH 5991 (Hybrid) - V2; Early Composite- V3; Local -V4]. The plot size was $21.6 \mathrm{~m}^{2}(7.2 \mathrm{~m} \mathrm{X}$ $3.0 \mathrm{~m})$. Each treatment was replicated four times. Farm yard manure (FYM) @ $10 \mathrm{t} \mathrm{ha}^{-1}$ on dry weight basis was incorporated uniformly in all the plots and mixed well at the time of field preparation. Whole of P and K were applied @ $60 \mathrm{~kg} \mathrm{ha}^{-1}$ and $40 \mathrm{~kg} \mathrm{ha}^{-1}$, respectively at the time of sowing through single super phosphate $\left(16 \% \mathrm{P}_{2} \mathrm{O}_{5}\right)$ and muriate of potash $\left(60 \% \mathrm{~K}_{2} \mathrm{O}\right)$, respectively. $1 / 3^{\text {rd }} \mathrm{N}$ was applied at sowing and remaining $2 / 3^{\text {rd }} \mathrm{N}$ was top dressed in two equal splits i.e., at knee-high and silking stage. Weeds were managed by spraying atrazine @ $1.75 \mathrm{~kg} \mathrm{ha}^{-1}$ within 48 hours of sowing.

All the test varieties were sown on respective dates as per treatment schedule. Line sowing with a row to row spacing of $60 \mathrm{~cm}$ and plant to plant spacing of $20 \mathrm{~cm}$ to 
accommodate 8 plants $/ \mathrm{m}^{2}$. Data used for model evaluation were the means of four replications.

\section{Plant measurements}

The observations on dry matter accumulation were recorded at fortnightly interval. For these observations $1 \mathrm{~m}$ row length was marked with sticks at three observation units in the net plot area. Total number of plants $\mathrm{m}^{-1}$ row length were counted at emergence and at harvesting of maize crop and data reported as plants $\mathrm{m}^{-2}$. For the vegetative phase, phenology was recorded by counting the leaves' collar appearance on daily basis for all experiments. Number of plants bearing silk was counted on every alternate day when silk appearance started. The day when $50 \%$ of plants in observational row $(1 \mathrm{~m})$ borne the silk, the stage was considered to have reached and data was reported as days after sowing.

To establish physiological maturity stage, 2 cobs plot $^{-1}$ were randomly taken from sampling row on alternate days and dried in oven. Grains were threshed and 100 grains were counted and their weight was recorded. This procedure was continued till the two consecutive readings of 100-grain weight became constant. The earlier date was recorded as date of physiological maturity and data reported as days after sowing.

All the cobs borne by the plants growing in net plot area were counted at maturity stage and mean value was converted as number $\mathrm{m}^{-2}$. Five maize cobs were randomly selected from net plot area and total number of grains was counted with the help of digital grain counter after threshing and average was reported as number of grains $\operatorname{cob}^{-1}$. 100 grains were counted and weighed after drying to determine mean single grain weight.

The crop from the net plot was harvested with the help of sickles and was left for sun drying for 3-4 days, and then total produce was weighed and recorded as biological yield. The cobs were removed from the plants in the net plot area and weighed immediately after sheath removal. Five cobs were randomly selected, weighed and transferred to polythene bags. The grains of these five cobs were removed manually and weighed. The moisture content of grains was also measured immediately. The shelling percentage was calculated as per following formula:

$$
\text { Shelling percentage }=\frac{\text { Grain yield of } 5 \text { cobs }}{\text { Total weight of } 5 \text { cobs }} * 100
$$

To get the grain yield, the shelling percentage was multiplied by weight of cobs from net plot and after adjusting at $15 \%$ moisture content yield was then expressed as $\mathrm{kg} \mathrm{ha}^{-1}$.

\section{Crop model}

The crop model CERES-Maize (Jones and Kiniry, 1986) was used in this study. The model simulates daily growth, development and production of maize crop for any climatic and agronomic inputs. This model was chosen because of its ability to simulate both the stressed and potential yield and possibility to introduce multiple soil layer subroutines. 


\section{Model accuracy}

The data recorded on various parameters were subjected to statistical analysis, following Analysis of Variance techniques for Split Plot Design as described by Gomez and Gomez (1984) and were tested at 5\% level of significance to interpret the significant findings.

The accuracy of model prediction was evaluated by testing the significance of linear regression coefficients ('a' and ' $\mathrm{b}$ ') and degree of goodness of fit $\left(\mathrm{R}^{2}\right)$ between simulated and observed values. The root mean squared error (RMSE) between simulated and observed data were also used. RMSE is a frequently used measure of the differences between values predicted by a model or an estimator and the values actually observed from the thing being modeled or estimated. A smaller RMSE indicates less deviation of the simulated values from the observed values (McMaster et al., 1992). RMSE was further used to work out the coefficient of variation $(\mathrm{CV})$ between the observed and simulated values. $\mathrm{CV}$ was worked out with the following formula:

$$
\begin{gathered}
R M S E=\sqrt{\frac{1}{\mathrm{~N}} \sum_{i=1}^{n}\left(Y_{\mathrm{i}}-\mathrm{x}_{i}\right)^{2}} \\
\mathrm{CV}(\%)=\operatorname{RMSE} * 100 / \mu
\end{gathered}
$$

Where $\mathrm{N}$ is the number of observations and $\mu$ is the mean observed value, $\mathrm{Yi}$ and $\mathrm{Xi}$ are the simulated and observed values of $\mathrm{i}^{\mathrm{th}}$ observation.

\section{Genotypic coefficient}

The genotype file contains the genotypic coefficients, which describe the varietal characteristics, were worked out by using Gencalculator (GENCAL). Crop genotypic input data, which explains how the life cycle of a cultivar responds to its environment, are not usually available and therefore these are derived iteratively using Hunt's method (Hunt et al., 1993). Minimum crop data set required for these calculations include date of emergence, anthesis, maturity, grain yield, above ground biomass, grain density (grains $\mathrm{cob}^{-1}$ ) and individual grain weight. The coefficients calculated by the software were fine tuned to simulate the development stages and yield parameters. The procedure for determining coefficients involved running the model using range of values of each coefficient in the order indicated above, until the desired level of agreement between simulated and observed values were reached. CERES-Maize model requires 5 cultivar specific genotypic coefficients. The 'P' coefficients (P1, P2, and P5) predict flowering and maturity, while the genotypic coefficient (G2 and G3) represent the grain dry weight under non-limiting conditions (Table 2). 
Table 2. Genotypic coefficients for maize varieties used in the study

\begin{tabular}{|c|c|c|c|c|c|}
\hline $\begin{array}{l}\text { S. } \\
\text { No. }\end{array}$ & Genotypic Coefficients & KH-9451 & KH-5991 & $\begin{array}{c}\text { Early } \\
\text { Composite }\end{array}$ & Local \\
\hline 1 & $\begin{array}{l}\text { P1- Juvenile phase (expressed in } \\
\text { degree days) }\end{array}$ & 200 & 200 & 200 & 218 \\
\hline 2 & P2- Photoperiod sensitivity & 1.91 & 1.86 & 1.16 & 1.99 \\
\hline 3 & $\begin{array}{l}\text { P5-Thermal time from silking to } \\
\text { physiological maturity (in degree } \\
\text { days). }\end{array}$ & 660.4 & 643.8 & 642.0 & 611.4 \\
\hline 4 & $\begin{array}{l}\text { G2-Maximum possible number of } \\
\text { kernels per plant. }\end{array}$ & 933.0 & 829.0 & 756.0 & 740.0 \\
\hline 5 & $\begin{array}{l}\text { G3-Kernel filling rate during the } \\
\text { linear grain filling stage and under } \\
\text { optimum conditions ( } \mathrm{mg} / \mathrm{day} \text { ). }\end{array}$ & 8.5 & 8.5 & 8.5 & 8.5 \\
\hline 6 & $\begin{array}{l}\text { PHINT-Phylochron interval; the } \\
\text { interval in thermal time (degree } \\
\text { days) between successive leaf tip } \\
\text { appearance. }\end{array}$ & 38.9 & 38.9 & 38.9 & 38.9 \\
\hline
\end{tabular}

\section{Model validation}

CERES-Maize was validated for grain productivity (of different maize varieties of which the genotypic coefficients were worked out in this study) only for which reasonably good number of experimental data were available. Validation of the CERESMaize for grain yield was attempted by using reported/published data of several field experiments on maize conducted during and preceding to the year of present investigation. Input data viz. crop management practices (sowing date, fertilizer application, irrigation management, organic manure, etc.) weather data and soil characteristics were modified in accordance with the reported year and place of experimentation. Simulation runs were made and model predicted data was generated. Actually reported and simulated data were compared. CV and regression between observed and simulated data were worked out and tested for their statistical significance.

\section{Simulation guided management}

After the model being validated satisfactorily for prediction of grain yield, simulation guided management practices were worked out for yield maximization of different varieties. This was achieved by systematically altering the various management practices (time of sowing, time and methods of fertilizer $\mathrm{N}$ application) as input by using sensitivity analysis option in model and recording the output (grain yield) after each run. Following this procedure simulation guided management practices for yield maximization of maize under potential production and resource limiting (no $\mathrm{N}$ application) situations were worked out by running model over a period of 5 years. 
Irrigation levels and time of application was also considered to be an important resource that limit yield under field conditions. But the model did not simulate the effect of irrigation levels in maize. Therefore, simulated data could not be generated due to different irrigation schedules.

\section{Results}

\section{Phenology}

The genotypic coefficient P2 varied from 1.16 for early composite to 1.99 for local (Table 2). P1, G3 and PHINT coefficients were same for all the four varieties except P1 for local. There was considerable variation amongst varieties in P2, P5 and G2 coefficients, indicating their differential behavior to attain various development stages and sink capacity. The difference between simulated and observed days to flowering and physiological maturity of different varieties sown on different dates over the 2 years ranged from 0 to 7 days only. Therefore, Fig. 3 shows a close correspondence between observed and simulated number of days to flowering and physiological maturity with small CV of 3.46 and $2.30 \%$, respectively. Similarly, goodness of fit $\left(\mathrm{R}^{2}\right)$ as well as regression coefficients between observed and simulated data was significant.
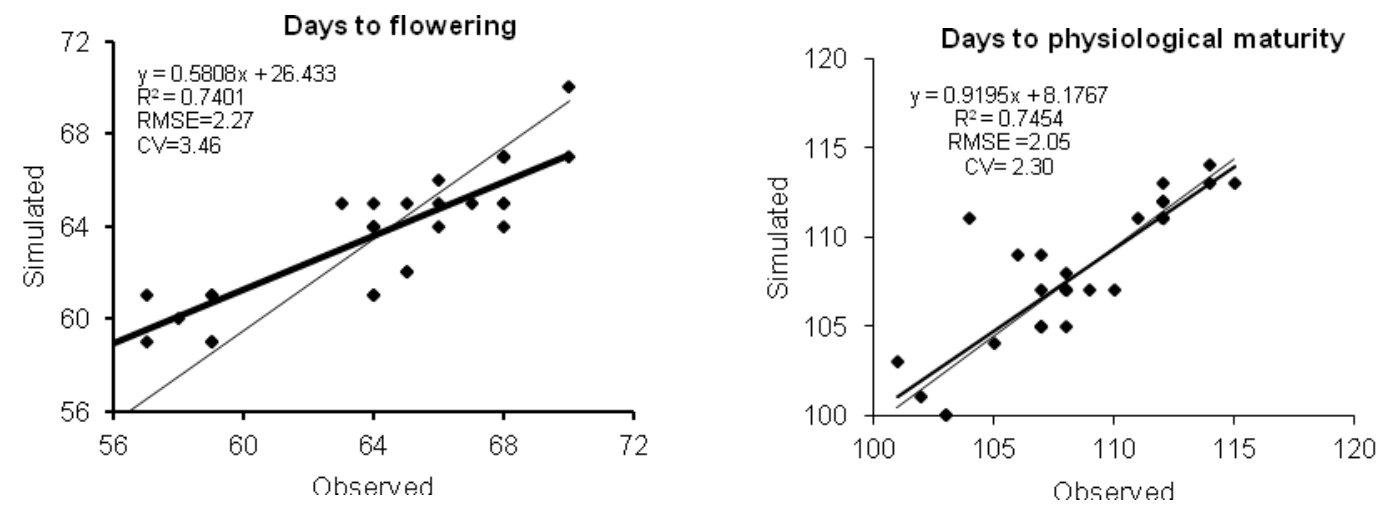

Figure 3. Observed and simulated phenology of maize crop (Straight line indicates the 1:1 line)

\section{Yield attributes}

Fig. 4 reveals that number of grains $\operatorname{cob}^{-1}$ simulated by the model matched closely with observed values. Consequently, the goodness of fit $\left(\mathrm{R}^{2}=0.545\right)$ between observed and simulated values was significant. CV was also within the acceptable level of $8.93 \%$. Similarly significant association between observed and simulated values of grain numbers $\mathrm{m}^{-2}$ was supported by significant $\mathrm{R}^{2}$ (Fig. 4) as worked out by comparison of calculated F- ratio with tabulated F-ratio value. Lower values of CV ( 9 and 10\%) also supports the fact that model estimated the parameter with a reasonable degree of reliability. Unlike number of grains, single grain weight was not correctly simulated by the model and the association between simulated and observed values was not significant (Fig. 4). Consequently, the goodness of fit between observed and simulated data was very poor $\left(\mathrm{R}^{2}=0.002\right)$ and higher $\mathrm{CV}(13.78 \%)$. 

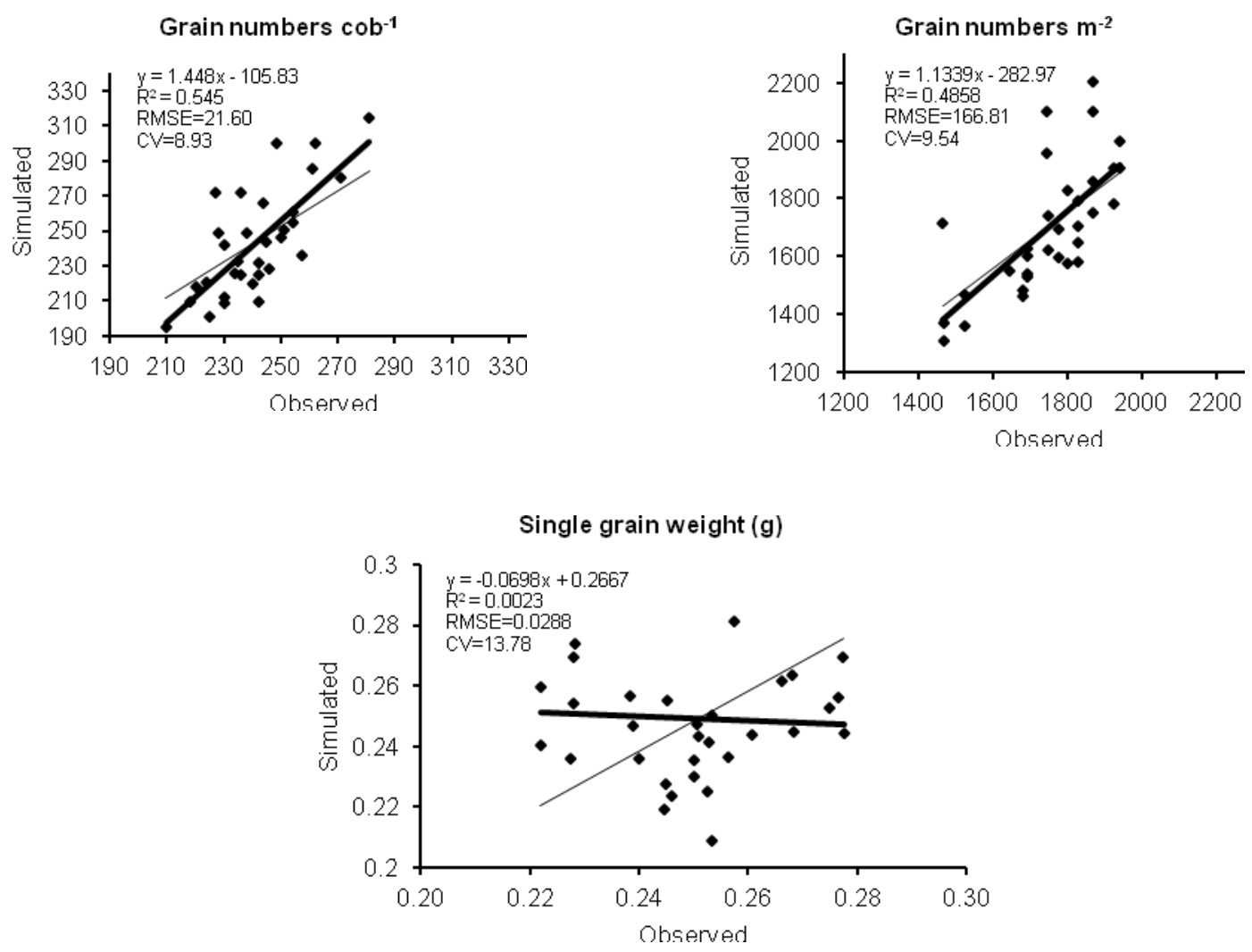

Figure 4. Observed and simulated yield attributes of maize crop (Straight line indicates the 1:1 line)

\section{Yield}

Like the development stages, grain yield was very well simulated by the model. Significant association between observed and simulated grain yield values were indicated by significant coefficients of regression and slope of regression line $(0.875)$ (Fig. 5). The goodness of fit $\left(\mathrm{R}^{2}=0.843\right)$ between simulated and observed field data was also significant. Satisfactory performance of the model in predicting the grain yield is further suggested by very low CV (6.95\%) which is very well within the acceptable limits. The simulated yields ranged from $3336 \mathrm{~kg} \mathrm{ha}^{-1}$ for the local to $5341 \mathrm{~kg} \mathrm{ha}^{-1}$ for the hybrid KH- 9451 and the observed yields ranged from $3046 \mathrm{~kg} \mathrm{ha}^{-1}$ for local to 5137 $\mathrm{kg} \mathrm{ha}^{-1}$ for the hybrid KH- 9451 (Table 3).

Table 3. Observed and simulated grain yield of maize $\left(\mathrm{kg} \mathrm{ha}^{-1}\right)$ [Pooled over two years] 


\begin{tabular}{|c|c|c|c|c|c|c|c|c|c|c|}
\hline \multirow{3}{*}{$\begin{array}{l}\text { Dates of } \\
\text { sowing }\end{array}$} & \multicolumn{10}{|c|}{ Varieties } \\
\hline & \multicolumn{2}{|c|}{ КН- 9451} & \multicolumn{2}{|c|}{ KH- 5991} & \multicolumn{2}{|c|}{$\mathrm{EC}$} & \multicolumn{2}{|c|}{ Local } & \multicolumn{2}{|c|}{ Mean } \\
\hline & Obs. & Sim. & Obs. & Sim. & Obs. & Sim. & Obs. & Sim. & Obs. & Sim. \\
\hline D1 & 5124 & 5341 & 4369 & 4686 & 4019 & 3917 & 3690 & 3948 & 4300 & 4473 \\
\hline D2 & 5137 & 5077 & 4369 & 4480 & 4001 & 4286 & 3757 & 3796 & 4316 & 4410 \\
\hline D3 & 4492 & 4740 & 3874 & 4134 & 3463 & 3739 & 3410 & 3498 & 3809 & 4028 \\
\hline D4 & 4051 & 4444 & 3564 & 3894 & 3280 & 3686 & 3046 & 3336 & 3485 & 3840 \\
\hline Mean & 4701 & 4900 & 4044 & 4298 & 3691 & 3907 & 3476 & 3644 & & \\
\hline RMSE & & & & & & & & & & 276.98 \\
\hline $\mathrm{CV}$ & & & & & & & & & & 5.57 \\
\hline
\end{tabular}

Like grain yield, stover yield was also simulated fairly well. Although the value of $\mathrm{R}^{2}=0.4961$ as well as the regression coefficients $(\mathrm{a}=2401$ and $\mathrm{b}=0.5575)$ between observed and simulated data were lower than those for grain yield, yet these were statistically significantly at 5\% level of significance (Fig. 5). Thus the model predictions are considered to be reliable and acceptable.

Mean biological yield predicted by the model agreed reasonably well with mean measured biological yield. Simulated values of biological yield of maize generated by the model were consistently lower than the measured values of all the treatments. However, association between simulated and observed data were significant with $\mathrm{R}^{2}=0.7747$. The intercept as well as the slope of regression line were also found to be statistically significant (Fig. 5). CV was also within acceptable levels and lower values of this coefficient $(10.73 \%)$ further support the biological yield prediction by model was reasonability good. Fig. 5 revealed that the association between simulated and observed harvest index values were significant $\left(R^{2}=0.4622\right)$. Significant values of intercept and slope of regression line also authenticate the significant association. 

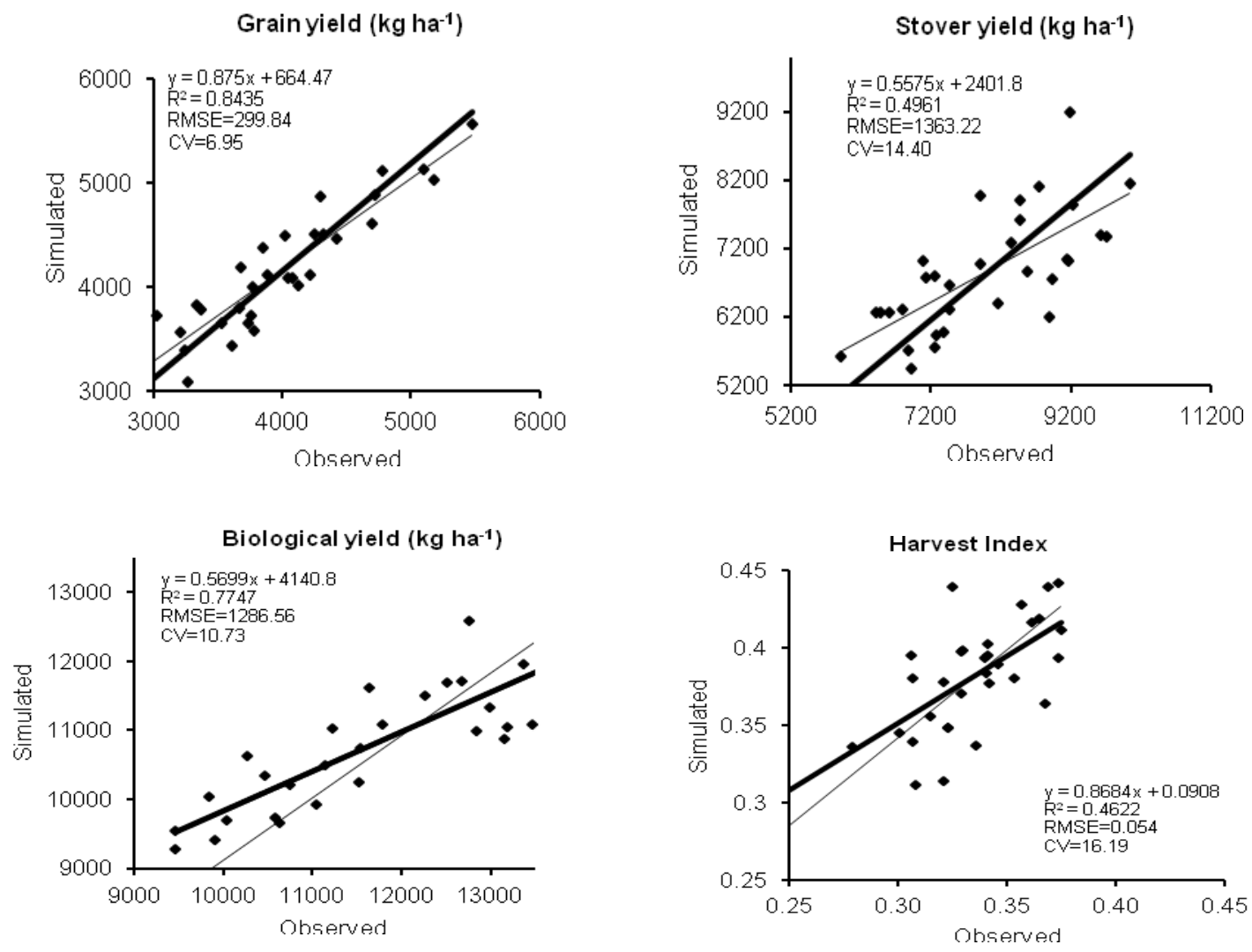

Figure 5. Observed and simulated yield and harvest index of maize crop (Straight line indicates the 1:1 line)

\section{Nitrogen content and uptake}

Simulated $\mathrm{N}$ content in maize grains were consistently, higher than the observed values. The regression line between observed vs. simulated data presented in Fig. 6 showed that the $\mathrm{R}^{2}(0.315)$ was not significant. The simulated and observed values for uptake of $\mathrm{N}$ in grains were significantly associated as supported by the tests of significance for intercept and slope of regression line. Similarly goodness of fit $\left(\mathrm{R}^{2}=0.8328\right)$ between simulated and observed data was significant. RMSE value was $6.70 \mathrm{~kg} \mathrm{ha}^{-1}$ and CV $9.89 \%$. The association between simulated and observed values for uptake of $\mathrm{N}$ in stover was also significant (Fig. 6). Goodness of fit $\left(\mathrm{R}^{2}=0.462\right)$ between the two values was also significant. RMSE value was $10.56 \mathrm{~kg} \mathrm{ha}^{-1}$. For total $\mathrm{N}$ uptake in maize, association between simulated and observed values was significant (Fig. 6). Goodness of fit $\left(\mathrm{R}^{2}=0.8065\right)$ was significant and RMSE was $23.17 \mathrm{~kg} \mathrm{ha}^{-1}$. CV was also on lower side $16.57 \%$. In general, the model underestimated the $\mathrm{N}$ uptake in all the treatments. 

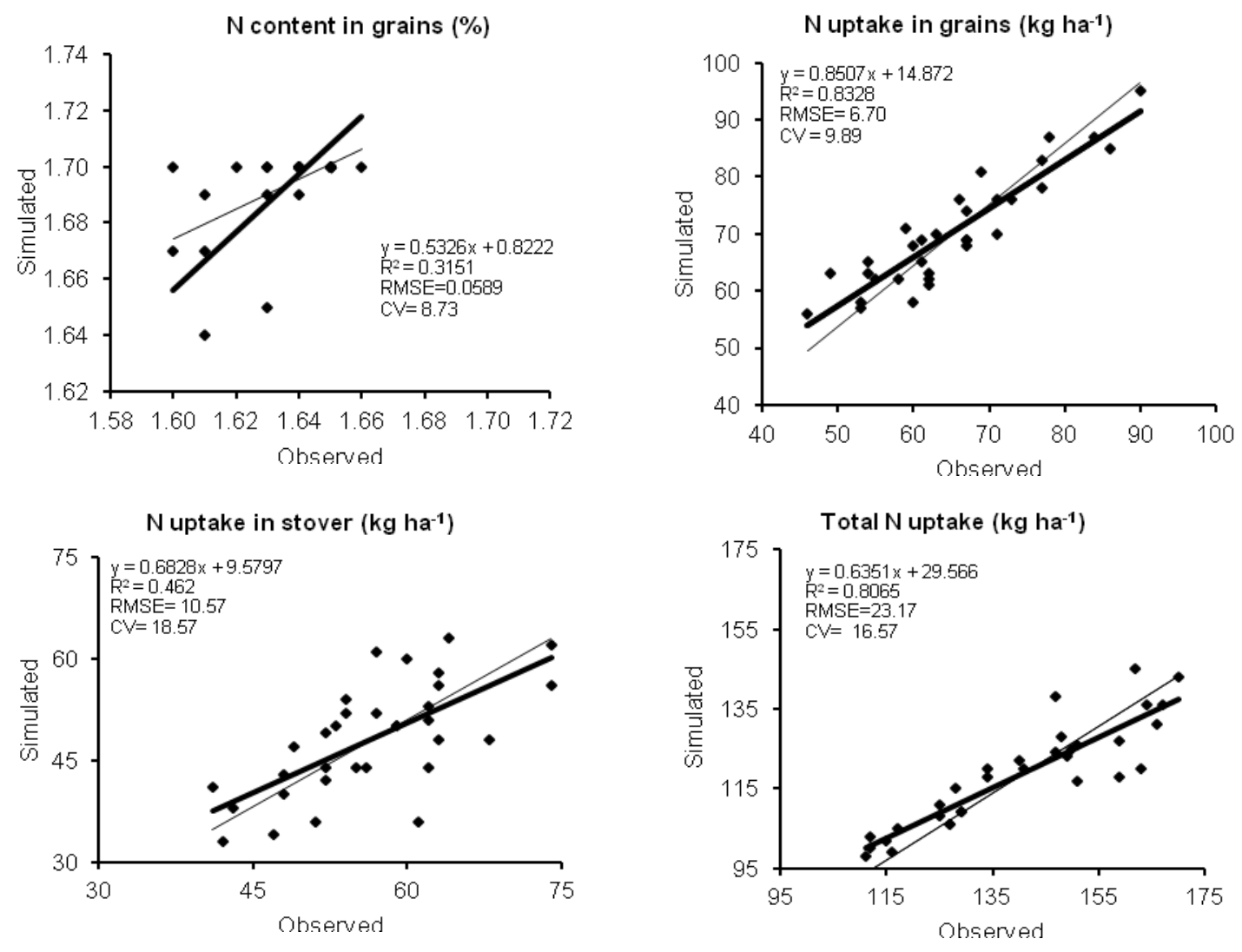

Figure 6. Observed and simulated nitrogen content and uptake of maize crop (Straight line indicates the 1:1 line)

\section{Validation of CERES-Maize}

Validation of the CERES-Maize for grain yield was attempted by using reported/published data of several field experiments on maize conducted during and preceding to the year of present investigation and the data is presented in Table 4. A perusal of Table 4 revealed that deviation of grain yield simulated by the model varied from (-)1090 to $10 \mathrm{~kg} \mathrm{ha}^{-1}$ obtained from different experiments.

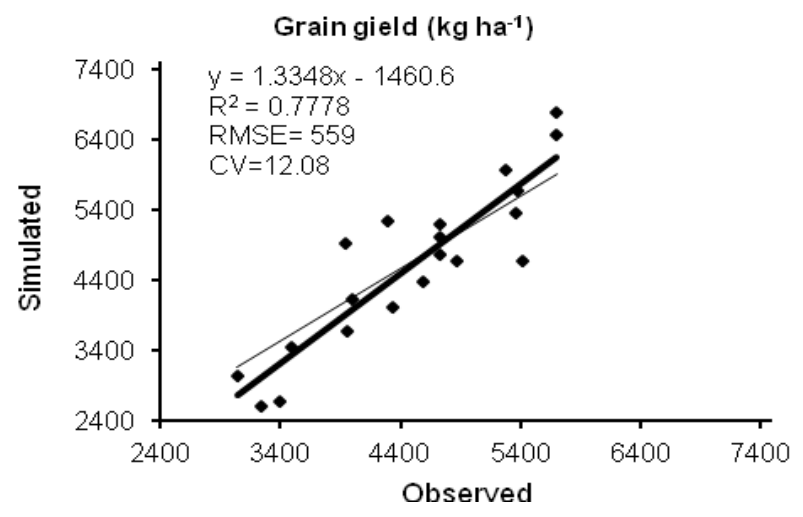

Figure 7. Validation of CERES-Maize model for grain yield (Straight line indicates the 1:1 line) 
Fig. 7 indicates that the simulated and observed values of grain yield for all the four varieties were close in all the experiments. Simulated and observed values were significantly associated as supported by high value of goodness of fit $\left(R^{2}=0.7778\right)$. This was further supported by tests of significance of intercept and slope of regression line. The RMSE value was $559 \mathrm{~kg} \mathrm{ha}^{-1}$ which further reveals the level of precision of model in yield prediction. CV was also within an acceptable limit of $12 \%$. All these statistical tools indicate that the CERES-Maize model was validated with a fair degree of accuracy and hence can be used as a decision support system and work out simulation guided management practices for yield maximization of maize under different resource base situation.

Table 4. Grain yield $\left(\mathrm{kg} \mathrm{ha}^{-1}\right)$ data used for validation of CERES-Maize model

\begin{tabular}{c|c|c|c}
\hline Experiment No. & \multicolumn{3}{|c}{ Grain yield (kg ha $\left.{ }^{-1}\right)$} \\
\cline { 2 - 4 } & Observed & Simulated & Deviation from observed \\
\hline 1 & 4920 & 3944 & -976 \\
2 & 4670 & 4863 & 193 \\
3 & 2670 & 3399 & 729 \\
4 & 5010 & 4724 & -286 \\
5 & 3670 & 3952 & 282 \\
6 & 5180 & 4724 & -456 \\
7 & 5240 & 4299 & -941 \\
8 & 4011 & 4339 & 328 \\
9 & 2593 & 3235 & 642 \\
10 & 5350 & 5364 & 14 \\
11 & 5958 & 5272 & -686 \\
12 & 5671 & 5370 & -301 \\
13 & 4670 & 5415 & 745 \\
14 & 4120 & 4001 & -119 \\
15 & 6469 & 5695 & -774 \\
16 & 6788 & 5698 & -1090 \\
17 & 4380 & 4586 & 206 \\
18 & 4760 & 4724 & -36 \\
19 & 3450 & 3496 & 46 \\
20 & 3030 & 3040 & 10 \\
\hline
\end{tabular}

\section{Simulation guided management practices}

The validated model was used to design agronomic practices for yield maximization of maize. From simulated results (Table 5) it was concluded that best time for sowing of KH 9451 and KH 5991 hybrids was last week of April to first week of May. Grain yield of both the hybrids increased with increase in level of $\mathrm{N}$ and up to $90 \mathrm{~kg} \mathrm{~N} \mathrm{ha}^{-1}$. The best schedule for application of $\mathrm{N}$ was $60: 30 \mathrm{~kg} \mathrm{ha}^{-1}$ i.e. $60 \mathrm{~kg} \mathrm{~N}$ at the time of sowing and $30 \mathrm{~kg} \mathrm{~N}$ at knee high stage. Application of $\mathrm{N}$ at silking did not show any appreciable increase in yield. With these management practices hybrid 9451 registered 51-5.5 $\mathrm{t} \mathrm{ha}^{-1}$ yield over the years. Under potential production situation (no $\mathrm{N}$ stress and 
no water stress) this variety has a yield potential of 6.0-6.4 $\mathrm{t} \mathrm{ha}^{-1}$. However under resource constraints situation i.e. under no nitrogen and rainfed conditions the yield declined to 27-29 q ha ${ }^{-1}$. Grain yield of second hybrid, KH 5991 with $60: 30 \mathrm{~kg} \mathrm{~N} \mathrm{ha}^{-1}$ was 4.5-4.8 $\mathrm{t} \mathrm{ha}^{-1}$ over the years. Under potential production situation this variety has a yield potential of 48-55 $\mathrm{q} \mathrm{ha}^{-1}$. However under resource constraints situation i.e. under no $\mathrm{N}$ and rainfed conditions the yield declined to 2.3-2.6 $\mathrm{t} \mathrm{ha}^{-1}$. Early composite being an early maturing variety, the appropriate time of sowing for this variety was worked out to be first week of May. This variety also responded upto $90 \mathrm{~kg} \mathrm{~N} \mathrm{ha}^{-1}$. Grain yield leveled off at $90 \mathrm{~kg} \mathrm{~N} \mathrm{ha}^{-1}$. The best schedule for application of $\mathrm{N}$ was same as for the hybrids. With these management practices this variety registered 3.8-4.4 $\mathrm{t} \mathrm{ha}^{-1}$ yield over the years. Under potential production situation this variety has a yield potential of 4.2-4.8 $\mathrm{t} \mathrm{ha}^{-1}$. However, under resource constraints situation i.e. under no nitrogen and rainfed conditions the yield declined to 2.2-2.6 $\mathrm{t} \mathrm{ha}^{-1}$.

'Local' being a long duration variety, earlier sowing during second fortnight of May was better. Local was also found to be fertilizer responsive and yield increased with increase in $\mathrm{N}$ upto $120 \mathrm{~kg} \mathrm{~N} \mathrm{ha}^{-1}$. The fertilizer schedule for this variety worked out to be $60: 30: 30 \mathrm{~kg} \mathrm{~N}^{-1}$ i.e. $60 \mathrm{~kg}$ at the time of sowing, $30 \mathrm{~kg}$ at the time at knee high stage and $30 \mathrm{~kg} \mathrm{~N}$ at silking stage. This variety has a yield potential of 4.2-4.5 $\mathrm{t} \mathrm{ha}^{-1}$ under potential production situation and 1.8-2.2 $\mathrm{t} \mathrm{ha}^{-1}$ under resource constraints situation i.e. under no nitrogen and rainfed conditions.

Table 5. Simulation guided management practices for yield maximization of maize

\begin{tabular}{l|c|c|c|c}
\hline Variety & \multirow{2}{*}{$\begin{array}{c}\text { Optimum Time of } \\
\text { Sowing }\end{array}$} & \multicolumn{3}{|c}{ Grain Yield (t ha-1) } \\
\cline { 3 - 5 } & $\begin{array}{c}\text { Without N } \\
\text { application }\end{array}$ & $\begin{array}{c}\text { Optimum N } \\
\text { application }\end{array}$ & Potential yield \\
\hline KH 9451 & $\begin{array}{c}\text { Last week of April to } \\
\text { first week of May }\end{array}$ & $2.7-2.9$ & $\begin{array}{c}51-55 \\
\left(60+30 \mathrm{~kg} \mathrm{~N} \mathrm{ha}^{-1}\right)^{*}\end{array}$ & $6.0-6.4$ \\
KH 5991 & $\begin{array}{c}\text { Last week of April to } \\
\text { first week of May }\end{array}$ & $2.3-2.6$ & $\begin{array}{c}45-48 \\
\left(60+30 \mathrm{~kg} \mathrm{~N} \mathrm{ha}^{-1}\right)\end{array}$ & $4.8-5.5$ \\
Early & $\begin{array}{c}\text { First week of May } \\
\text { Composite }\end{array}$ & $2.2-2.6$ & $\begin{array}{c}38-44 \\
\left(60+30 \mathrm{~kg} \mathrm{~N} \mathrm{ha}^{-1}\right)\end{array}$ & $4.2-4.8$ \\
Local & $\begin{array}{c}\text { Second fortnight of } \\
\text { May }\end{array}$ & $1.8-2.2$ & $\begin{array}{c}35-43 \\
\left(60+30+30 \mathrm{~kg} \mathrm{~N} \mathrm{ha}^{-1}\right) \#\end{array}$ & $4.2-4.5$ \\
\hline
\end{tabular}

* $60 \mathrm{~kg} \mathrm{~N} \mathrm{ha}^{-1}$ at the time of sowing and $30 \mathrm{~kg} \mathrm{~N} \mathrm{ha}^{-1}$ at knee high stage

\# $60 \mathrm{~kg} \mathrm{~N} \mathrm{ha}^{-1}$ at sowing time, $30 \mathrm{~kg} \mathrm{~N} \mathrm{ha}^{-1}$ at knee high stage and $30 \mathrm{~kg} \mathrm{~N} \mathrm{ha}^{-1}$ at silking stage

\section{Discussion}

The CERES-Maize model was able to simulate phenology of 4 maize varieties grown in North West Himalayas in India. Smaller value of CV indicates that the model's performance was satisfactory in this parameter. Roman-Paoli et al. (2000), Gungula et al. (2003) and Tojo Soler et al. (2007) have also reported close prediction of days to flowering in maize by using CERES-Maize in different environments. Model 
closely simulated number of grains per cob $\left(\mathrm{R}^{2}=0.545\right)$, number of grains $\mathrm{m}^{-2}$ $\left(\mathrm{R}^{2}=0.485\right)$ but could not simulate single grain weight $\left(\mathrm{R}^{2}=0.002\right)$.

Grain yield was very well simulated by the model. In general, simulated grain yield data were slightly higher than the observed data. Mastrorilli et al. (2003) reported less than $13 \%$ variation in grain yield of simulated and observed grain yield under Mediterranean conditions by using CERES-Maize model. Like grain yield, stover yield was also simulated fairly well and the association between observed and simulated values was significant. In general, the model under predicted stover and total biological yields and over-estimated the harvest index. The model failed to simulate $\mathrm{N}$ content in grains of all varieties at all sowing dates. But $\mathrm{N}$ uptake in grains, stover as well as total uptake in grain+stover was closely simulated by model.

CERES-Maize model was validated with a fair degree of accuracy as supported by high value of goodness of fit between the observed and simulated data, low RMSE (559 $\left.\mathrm{kg} \mathrm{ha}^{-1}\right), \mathrm{CV}(12.08 \%)$ and hence can be used as a decision support system for prediction of grain yield. Best time for sowing of both hybrids was worked out to be last week of April. While for early composite, first week of May proved advantageous and for local, second fortnight of April was the appropriate time. The best schedule of $\mathrm{N}$ application was $60+30 \mathrm{~kg} \mathrm{~N}^{-1}, 60 \mathrm{~kg} \mathrm{~N} \mathrm{ha}^{-1}$ at sowing time and $30 \mathrm{~kg} \mathrm{~N}$ at knee high for all varieties except for local where it was $60 \mathrm{~kg} \mathrm{~N} \mathrm{ha}^{-1}$ at sowing and $30 \mathrm{~kg}$ each at knee high and silking stages.

\section{REFERENCES}

[1] Anapalli, S.S., Ma, L., Nielsen, D.C., Vigil, M.F., Ahuja, L.R. (2005): Simulating planting date effects on corn production using RZWQM and CERES-Maize models. Agronomy Journal 97: 58-71.

[2] Black, C.A. (1965): Method of soil analysis. Part 2. American Society of Agronomy. Inc. Publisher, Madison, Wisconsin, USA.

[3] Boggess, W.G., Ritchie, J.T. (1988): Economic and risk analysis of irrigation decisions in humid regions. - Journal of Production Agriculture 1: 116-122.

[4] Bosch, D.J., Ross, B.B. (1990): Improving irrigation schedules to increase returns and reduce water use in humid regions. - Journal Soil Water Conservation 45: 486-489.

[5] Fischer, G., Shah, M., van Velthuizen, H., Nachtergaele, F.O. (2000): Global agroecological assessment for agriculture in the $21^{\text {st }}$ century. - In: Proceedings of the IIASA, Vienna.

[6] Gomez, K.A., Gomez, A.A. (1984): Statistical Procedures for agricultural research with emphasis on rice. - Wiley publishers, New York, USA, pp 680.

[7] Gungula, D.T., Kling, J.G., Togun, A.O. (2003): CERES-Maize predictions of maize penology under nitrogen stressed conditions in Nigeria. - Agronomy Journal 95: 892899.

[8] Hammer, G.L., Kropff, M.J., Sinclair, T.R., Porter, J.R. (2002): Future contributions of crop modeling from heuristics and supporting decision making to understanding genetic regulation and aiding crop improvement. - European Journal of Agronomy 18: 15-31.

[9] Hansen, J.W. (2002): Realizing the potential benefits of climate prediction to agriculture: issues, approaches, challenges. - Agricultural Systems 74: 309-330.

[10] Hoogenboom, G., Jones, J.W., Wilkens, P.W., Porter, C.H., Batchelor, W.D., Hunt, L.A., Boote, K.J., Singh, U., Uryasev, O., Bowen, W.T., Gijsman, A.J., du Toit, A., White, J.W., Tsuji, G.Y. (2004): Decision Support System for Agrotechnology Transfer Version 4.0 CD-ROM. - University of Hawaii, Honolulu, HI. 
[11] Hunt L.A., Pararajasingham, S., Jones, J.W., Hoogenboom G., Imamura, D.T., Ogoshi, R.M. (1993): GENCALC: Software to facilitate the use of crop models to analyse field experiment. - Agronomy Journal 85: 1090-1094.

[12] Jackson, M.L. (1967): Soil Chemical Analysis. - Prentice Hall of India, New Delhi pp. 183-190.

[13] Jones, C.A., Kiniry, J.R. (1986): CERES-Maize. A simulation model of maize growth and development. - Texas A\&M Univ. Press College Station.

[14] Jones, J.W., Hoogenboom, G., Porter, C.H., Boote, K.J., Batchelor, W.D., Hunt, L.A., Wilkens, P.W., Singh, U., Gijsman, A.J., Ritchie, J.T. (2003): DSSAT Cropping System Model. - European Journal of Agronomy 18: 235-265.

[15] Mastrorilli, M., Katerji, N., Ben Nouna, B. (2003): Using the CERES-Maize model in a semi-arid Mediterranean environment. Validation of three revised versions. - European Journal of Agronomy 19: 125-134.

[16] McMaster, G.S., Wilhelm, W.W., Morgan, J.A. (1992): Simulating winter wheat shoot apex phenology. - Journal of Agricultural Sciences, Cambridge 119: 1-12.

[17] Olsen, S.R., Cole, C.V., Watanabe, F.S., Dean, L.A. (1954): Estimation of available phosphorous in soil by extraction with sodium bicarbonate. - USDA, Circ. 939. pp. 19-23 (C.F. Methods of soil Analysis Ed. By C.A. Black. Agronomy No. 9. American society of Agronomy, Madison, Wisconsin, 1965 pp. 1044-1046).

[18] Piper, C.S. (1966): Soil and Plant analysis. - Hans Publishers, Bombay, India, pp. 223227.

[19] Reddy, T.Y., Umamaheshwari, P. (2004): Precision agriculture. - Advances in Plant Physiology 7: 537-558.

[20] Richards, L.A. (1965): Physical condition of water in soil. - In: Methods of soil analysis, American Society of Agronomy, Madison, Wisconsin, Monograph 9: 128-152.

[21] Ritchie, J.T., Singh, U., Godwin, D.C., Bowen, W.T. (1998): Cereal growth, development and yield. - In: Tsuji, G.Y., Hoogenboom, G., Thornton, P.K. (Eds.), Understanding options for agricultural production. Kluver Academic Publishers, Dordrecht. The Netherlands, pp. 79-98.

[22] Roman-Paoli, E., Welsh, S.M., Vanderlip, R.L. (2000): Comparing genetic coefficient estimation methods using the CERES-Maize model. - Agriculture Systems 65: 29-41.

[23] Tojo Soler, C.M., Sentelhas, P.C., Hoogenboom, G. (2007): Application of the CSMCERES-Maize model for planting date evaluation and yield forecasting for maize grown off-season in a subtropical environment. - European Journal of Agronomy 27: 165-177.

[24] Tsuji, G.Y., Jones, J.W., Hoogenboom, G., Hunt, L.A., Thornton, P.K. (1994): Introduction. - In: Tsuji, G., Uehara, Y., Balas, G.S. (Eds.), DSSAT v3, Decision Support System for Agrotechnology Transfer, vol. 1. University of Hawaii, Honolulu, Hawaii. 